\title{
The Production of a Thin Wire of Ti-Nb-Ta-Zr Shape Memory Alloy for Medical Devices
}

Elena O Nasakina*, Sergey V Konushkin, Maria I Baskakova, Ilya M Fedyuk, Konstantin V Sergienko, Alexander S Baikin, Mikhail A Kaplan, Mikhail A Sevostyanov and Alexey G Kolmakov

Baykov Institute of Metallurgy and Material Sciences (IMET RAS), Russia

\begin{abstract}
Alloys possessing a shape memory effect and mechanical characteristics similar to the behavior of living tissues have been already used for years as the material for production of medical devices, including implants, for example stents, without the need for additional devices except catheter-carrier. However, most of these alloys contain elements (including on its surface) which is toxic for organism. To satisfy the requirements of biochemical compatibility, the alloy should contain only safe elements as alloy components, which include: $\mathrm{Ti}, \mathrm{Nb}, \mathrm{Ta}, \mathrm{Zr}$. The possibility of obtaining of $\mathrm{Ti}-\mathrm{Nb}-\mathrm{Ta}-\mathrm{Zr}$ thin wire was investigated. The structure was determined with the use of the optical microscope, $\mathrm{X}$-ray diffractometer, scanning electron microscope (SEM) and Auger spectrometer. Optimal conditions for smelting were chosen. It was noted that a uniform structure was obtained for all compositions, before and after homogenizing annealing. The ingots have a dendritic structure. Niobium and zirconium were uniformly distributed throughout the sample, tantalum was concentrated in the dendrites themselves, titanium was predominantly in the regions between the dendritic axes, but is also found in it. X-ray diffractometry indicates that the elements of the alloy were not distributed in it by separate fragments, but were united in a single structure. The optimal annealing temperature of Ti-(20-30) Nb$(10-13) \mathrm{Ta}-5 \mathrm{Zr}$ alloys was noted in the range from 600 to $900^{\circ} \mathrm{C}$. The grain boundaries after plastic deformation and heat treatment were not identified in a microstructural analysis, which indicates that there was no recrystallization. It is possible that nanostructure was formed. The morphology of wires of any composition after drawing shows a high heterogeneity, two types of surfaces of different composition alternate - areas with a high content of carbon and with a high content of oxygen were observed. After mechanical treatment the surface, its uniformity increases.
\end{abstract}

Keywords: Shape memory alloy; Superelasticity; Titanium; Tantalum; Niobium; Zirconium

\section{Introduction}

Materials used in medicine for the manufacture of implants, should exhibit a set of properties that ensure the compatibility of this medical products and the body, such as super-elasticity, low values of the Young's modulus, high corrosion resistance and biocompatibility. Low Young's modulus (50-80 GPa) and super-elastic behavior, close to the behavior of living tissue, are exhibited by alloys with shape memory effect, especially Ti-Ni alloys. SME promotes the production of the least traumatic self-expanding devices [1]. Ti-Ni alloys have been already used for years as the material for production of medical devices, including implants, for example stents (Figure 1), without the need for additional devices except catheter-carrier. However, the toxic properties of nickel limit its further medical use in a number of developed countries (Japan, Germany and others) [2-14]. Different authors give completely different durations and magnitudes of the nickel ion release from nitinol into the medium, as well as level of biocompatibility and electro-chemical corrosion characteristics.

To satisfy the requirements of biochemical compatibility, the alloy should not cause inflammatory processes and allergic reactions in the body. The basis for this is the use of only safe elements as alloy components, which include: $\mathrm{Ti}, \mathrm{Nb}, \mathrm{Ta}, \mathrm{Zr}$. It was shown that $\mathrm{Ti}-(22-25)$ $\mathrm{Nb}$ and $\mathrm{Ti}-(25.5-27) \mathrm{Nb}$ (at.\%) alloys exhibit super-elasticity and shape memory effect [15]. Great attention was attracted to studies on the effect of tantalum on the functional properties of $\mathrm{Ti}-\mathrm{Nb}-\mathrm{Ta}-\mathrm{Zr}$ alloys [16]. It is found that in the Ti-30Nb-XTa-5Zr alloy, the mechanical properties are nonlinearly dependent on changes in tantalum concentration. At the same time, the most perfect super-elastic properties are observed in $\mathrm{Ti}-30 \mathrm{Nb}-(5-10) \mathrm{Ta}-5 \mathrm{Zr}$ alloys, while alloys with higher tantalum content lose their tendency to super-elastic behavior. Also, alloying $\mathrm{Ti}-(\mathrm{Nb}, \mathrm{Ta})$ with zirconium alloys promotes hardening of the solid solution and reduces the probability of brittle $\omega$-phase formation, thereby improving the functional properties of metastable $\mathrm{Ti}-\mathrm{Nb}$ based memory alloys, and can have a $\beta$-stabilizing effect, which lowers the martensitic transformation temperature. It was shown that the $\mathrm{Zr}$ content in the range of $5 \%$ corresponds to the minimum Young's modulus for the alloys Ti-(13-35.5)Nb-(5-22) Ta-(4-7.2) Zr (weight\%) [17]. The alloy Ti-29Nb-13Ta-4,6Zr also exhibits high mechanical properties, important for biomedical alloys [18]. Thus, it is possible to consider $\mathrm{Ti}-(20-30) \mathrm{Nb}-(10-13) \mathrm{Ta}-5 \mathrm{Zr}$ alloys as promising materials for the manufacture of medical products such as "stent" and "cava filter".

The work was devoted to the development of a fundamentally new technology for the production of $\mathrm{Ti}-\mathrm{Nb}-\mathrm{Ta}-\mathrm{Zr}$ wire with a diameter of $280 \mu \mathrm{m}$ by the method of plastic deformation.

\section{Materials and Methods}

As charge materials, iodide titanium, iodide zirconium, technically pure niobium and technically pure tantalum were used (Table 1). For the investigations in this work, alloys of the following compositions

*Corresponding author: Elena O Nasakina, Baikov Institute of Metallurgy and Materials Science, Leninsky Prospect, Russia, Tel: 8(985)966-54-08; E-mail: nacakina@mail.ru

Received February 17, 2018; Accepted February 23, 2018; Published March 03 2018

Citation: Nasakina EO, Konushkin SV, Baskakova MI, Fedyuk IM, Sergienko KV et al. (2018) The Production of a Thin Wire of Ti-Nb-Ta-Zr Shape Memory Alloy for Medical Devices. J Material Sci Eng 7: 430. doi: 10.4172/2169-0022.1000430

Copyright: (c) 2018 Nasakina EO, et al. This is an open-access article distributed under the terms of the Creative Commons Attribution License, which permits unrestricted use, distribution, and reproduction in any medium, provided the original author and source are credited. 
were chosen: Ti-20Nb-10Ta-5Zr; Ti-20Nb-13Ta-5Zr; Ti-25Nb-10Ta5Zr; Ti-25Nb-13Ta-5Zr; Ti-30Nb-10Ta-5Zr; Ti-30Nb-13Ta-5Zr.

To select the optimal weight of the sample, when melting in a vacuum electric arc furnace, ingots with a mass of 15, 20, $30 \mathrm{~g}$ of Ti$30 \mathrm{Nb}-13 \mathrm{Ta}-5 \mathrm{Zr}$ alloy were produced. The alloy of this composition was chosen because of the largest content of refractory components, such as $\mathrm{Ta}$ and $\mathrm{Nb}$. Each ingot was melted 5 times.

To select the optimum number of re-melting in a vacuum electric arc furnace, $20 \mathrm{~g}$ hitches of selected compositions were made and melted 3, 5 and 7 times. Since the uniform distribution of Ta over the entire volume of the ingot is the most difficult task in the smelting process because of its refractory properties, the compositions with the largest content of this metal were chosen for testing the ingot production technology: 20Nb-13Ta-5Zr; Ti-25Nb-13Ta-5Zr; Ti-30Nb-13Ta-5Zr.

Melting was carried out in an electric arc furnace with a nonconsumable tungsten electrode LK8 (LEYBOLD-HERAEUS, Germany) in argon at a residual and operating pressure of $1.333 \mathrm{~Pa}$ and $0.203 \mathrm{MPa}$, respectively. In the process of the first 2-3 re-melts, a single ingot was obtained. The subsequent re-melting was aimed at obtaining a uniform chemical composition throughout the entire ingot. The duration of each melting of one ingot was 1-1.5 minutes. Further under these conditions, the obtained ingots were alloyed into a single ingot weighing $60 \mathrm{~g}$ in the process of two re-melting. The final ingot had a length of $60-70 \mathrm{~mm}$, a width of 20-25 mm, a height of 10-12 mm. Ingots of all compositions melted 7 times were additionally annealed in a vacuum of $6.667 \times 10^{-3}$ $\mathrm{Pa}$ at $600^{\circ} \mathrm{C}$ or $900^{\circ} \mathrm{C}$ for 12 hours. The resistance pit vacuum furnace SSHVZ-1.2.5/25-I3 (Russia) was used.

The ingots were heated in air to a temperature of $600^{\circ} \mathrm{C}$ for 15 minutes in a KYLS 20.18.40/10 furnace (HANS BEIMLER, Germany). Immediately after it the rolling took place on the reversible mill DUO-300 (Russia) in air to a rod section $10 \times 10 \mathrm{~mm}^{2}$. The subsequent annealing of the rods was carried out in a continuous resistance tube furnace PTS-2000-40-1200 (OOO "Lori-Termo", Russia).

Rotational forging of obtained blanks was consistently carried out on radial forging machines B2129.02, B2127.01, B2123.01 (Russia) with successive change of strikers to a cross section of $2 \mathrm{~mm}$. Pre-heating of blanks in air at a temperature of $600-650^{\circ} \mathrm{C}$ just before deformation was carried out in the furnace PTS-2000-40-1200.

The most responsible and controversial stage in the preparation of $\mathrm{Ti}-\mathrm{Nb}-\mathrm{Ta}-\mathrm{Zr}$ alloy is its production in the form of a wire in connection with possible processes of embrittlement of the material with undesirable accumulation of oxygen within the grain boundaries.

With a wire diameter of $2 \mathrm{~mm}$ to a diameter of $0.4 \mathrm{~mm}$, the drawing was performed on a C7328/ZF machine (THE NORTHWEST

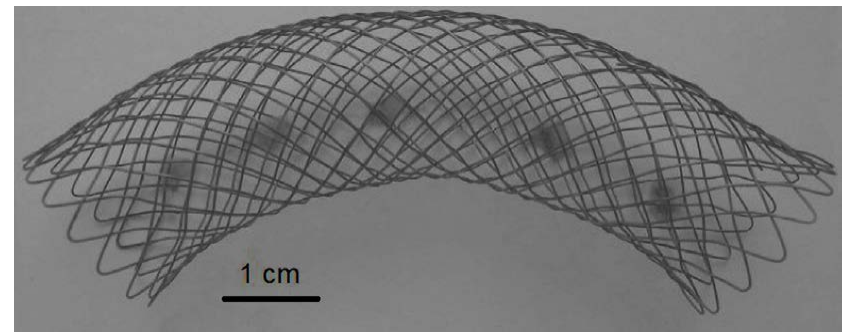

Figure 1: Patency restoration process: stent applied to restore esophagea and intestinal patency.
MACHIBE CO.LTD, China). A wire with a diameter of $0.4 \mathrm{~mm}$ to a diameter of $0.28 \mathrm{~mm}$ was dragged on a UDZWGW 100/8 machine (Germany) with a spinner pitch of $0.02 \mathrm{~mm}$. Drawing was held in the air. As a lubricant was used aquadag. The wire was also subjected to heat treatment, including already at the final diameter in order to stabilize the structure and properties of the material. The procedure was also carried out in a vacuum of $6.667 \times 10^{-3} \mathrm{~Pa}$ at $600^{\circ} \mathrm{C}$ for 12 hours.

The mechanical treatment was carried out by abrasive paper from 180 to 1000 grit and finally by GOI (State Optical Institute) paste to a mirror surface. The decrease in the diameter was to $10 \mu \mathrm{m}$ in comparison with the original.

To investigate the wire microstructure, the preliminary etching of the surface was carried out in a mixture of $1 \mathrm{~mL} \mathrm{HF}+2 \mathrm{~mL} \mathrm{HNO}_{3}+47$ $\mathrm{mL} \mathrm{H}_{2} \mathrm{O}$ composition for 2-3 min, upon termination of which the sample was washed several times in distilled water and dried in air. Investigations were carried out on an Axiovert 40 MAT optical metallographic microscope (Carl Zeiss, Germany) with digital image processing. To determine the phase composition, we used an Ultima IV X-ray diffractometer (Rigaku Co., Japan) in $\mathrm{Cu} \mathrm{Ka-radiation} \mathrm{on}$ the basis of Bragg-Brentano method. Phase analysis was prepared in the PDXL program complex using the ICDD database. The surface morphology and the layer-by-layer composition were investigated on a scanning election microscope (SEM) VEGA II SBU with the module INCA Energy for energy-dispersive analysis (TESCAN, Czech Republic) and on a JAMP 9500F Auger spectrometer (JEOL Co., Japan) in combination with ion etching at argon bombardment under an angle of $30^{\circ}$.

\section{Results and Discussion}

After melting, ingots were visually examined along the cross-section to search for undissolved particles of the original elements (Figure 2). There were no apparent undissolved particles. The uniformity of the elements distribution over the cross-section of the ingot after melting was determined by means of Auger spectroscopy. Figure 3 shows the arrangement of points in which the chemical composition was determined. Table 2 presents the results of a study of the chemical composition at selected points along the cross-section of ingots of $\mathrm{Ti}$ $30 \mathrm{Nb}-13 \mathrm{Ta}-5 \mathrm{Zr}$ alloy after three, five, or sevenfold re-melting. As can

\begin{tabular}{|c|c|c|c|c|}
\hline \multirow{2}{*}{ Material } & \multicolumn{4}{|c|}{ Element concentration (weight, \%) } \\
\cline { 2 - 5 } & $\mathbf{O}$ & $\mathbf{N}$ & $\mathbf{C}$ & $\mathbf{H}$ \\
\hline lodide titanium & 0.001 & 0.001 & 0.001 & 0.0001 \\
\hline lodide zirconium & 0.005 & 0.005 & 0.008 & 0.0001 \\
\hline Technically pure niobium & 0.0033 & 0.015 & 0.002 & 0.0002 \\
\hline Technically pure tantalum & 0.0017 & 0.011 & 0.006 & 0.0004 \\
\hline
\end{tabular}

Table 1: Content of impurities in charge materials.

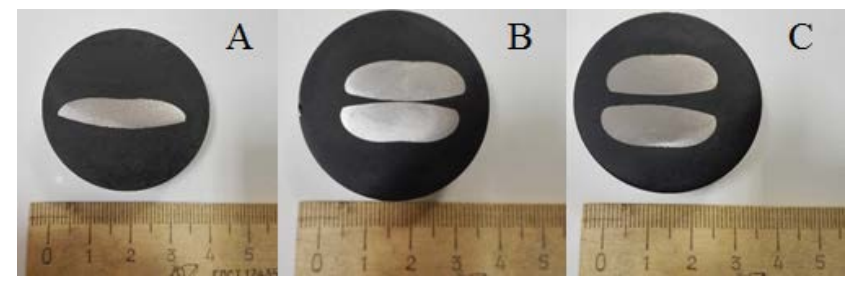

Figure 2: Cross-sections of $20 \mathrm{~g}$ ingots: a) of an Ti-20Nb-13Ta-5Zr alloy after threefold remelting; $b$ ) of an alloy of Ti-25Nb-13Ta- $5 \mathrm{Zr}$ after a three-fold (top) and five-fold (bottom) remelting; c) of an Ti-30Nb-13Ta-5Zr alloy after three (top) and five (below) remelting. 
be seen from the table, a three-fold re-melting of the ingots made it possible to obtain a fairly homogeneous chemical composition, but based on the general experience of alloys melting of refractory metals, it is recommended to use five- and sevenfold re-melting. The regularity was maintained for all compositions and did not change after annealing. For the further melting of ingots it was decided to use a seven-fold re-melting technology. The mass of ingots did not greatly affect the homogeneity of the elements distribution across the section. For the further smelting of ingots, it was decided to make twenty-gram weights.

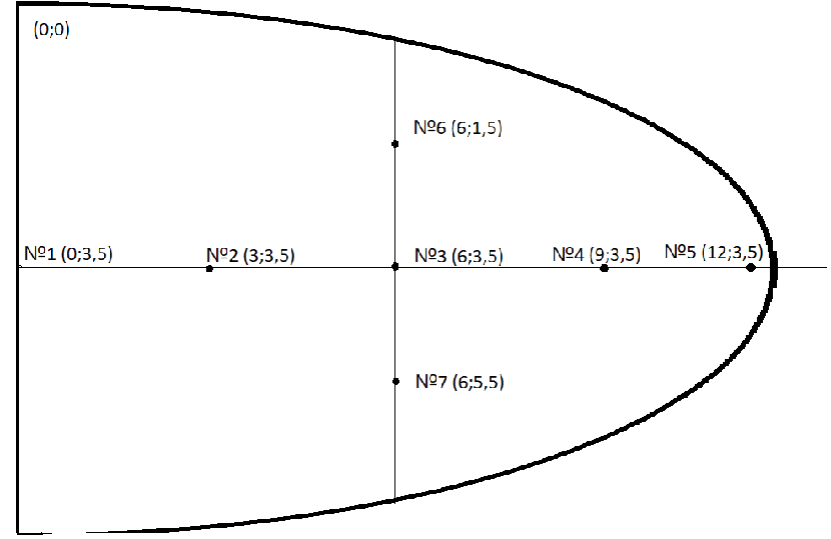

Figure 3: Arrangement of points for the uniformity analysis of the ingot chemical composition.

\begin{tabular}{|c|c|c|c|c|c|}
\hline & \multirow{2}{*}{$\begin{array}{c}\text { Analysis } \\
\text { point number }\end{array}$} & \multicolumn{4}{|c|}{ Element concentration (weight, \%) } \\
\hline & & $\mathrm{Nb}$ & Ta & $\mathrm{Ti}$ & $\mathrm{Zr}$ \\
\hline \multirow{8}{*}{$\begin{array}{l}\text { Threefold } \\
\text { remelting }\end{array}$} & 1 & 34.2 & 32.5 & 29.2 & 3.7 \\
\hline & 2 & 33.6 & 30 & 32.4 & 3.7 \\
\hline & 3 & 34 & 28.4 & 32.2 & 5 \\
\hline & 4 & 33.8 & 29.5 & 31.6 & 4.7 \\
\hline & 5 & 33.5 & 29.4 & 31.8 & 4.9 \\
\hline & 6 & 36.6 & 30.8 & 27.9 & 4.3 \\
\hline & 7 & 34.7 & 30.9 & 30.2 & 4.1 \\
\hline & Average & 34.34 & 30.21 & 30.76 & 4.34 \\
\hline \multirow{8}{*}{$\begin{array}{l}\text { Fivefold } \\
\text { remelting }\end{array}$} & 1 & 35.4 & 32.6 & 27.5 & 4.1 \\
\hline & 2 & 35.4 & 29.5 & 29.8 & 4.7 \\
\hline & 3 & 34.7 & 28 & 31.7 & 5.2 \\
\hline & 4 & 35.9 & 29.6 & 29.1 & 5 \\
\hline & 5 & 34.7 & 29.3 & 30.3 & 5.4 \\
\hline & 6 & 35.3 & 28.3 & 31 & 5 \\
\hline & 7 & 36 & 27.2 & 31.7 & 4.7 \\
\hline & Average & 35.34 & 29.21 & 30.16 & 4.87 \\
\hline \multirow{8}{*}{$\begin{array}{l}\text { Sevenfold } \\
\text { remelting }\end{array}$} & 1 & 36.4 & 34 & 24.6 & 5.5 \\
\hline & 2 & 35.3 & 32.2 & 27.7 & 5.4 \\
\hline & 3 & 34.6 & 29.6 & 30.2 & 5 \\
\hline & 4 & 33.8 & 25.6 & 34.6 & 5.6 \\
\hline & 5 & 34.4 & 27.1 & 32.7 & 5.4 \\
\hline & 6 & 34.9 & 28.3 & 31.4 & 6 \\
\hline & 7 & 33.4 & 26.2 & 34 & 6 \\
\hline & Average & 34.69 & 29.00 & 30.74 & 5.56 \\
\hline $\begin{array}{l}\text { Theoretical } \\
\text { significance }\end{array}$ & & 34.47 & 29.10 & 30.79 & 5.64 \\
\hline
\end{tabular}

Table 2: The distribution of elements in the Ti-30Nb-13Ta-5Zr alloy according to Auger spectroscopy (in accordance with the scheme in Figure 3) after three-, five-, sevenfold remelting.

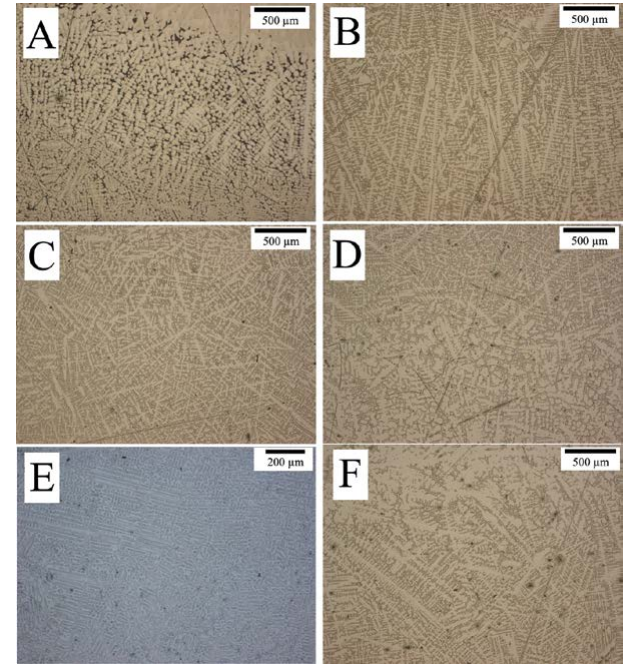

Figure 4: Microstructure of ingots after smelting: a) Ti-20Nb-10Ta-5Zr alloy b) Ti-20Nb-13Ta-5Zr alloy; c) Ti-25Nb-10Ta-5Zr alloy; d) Ti-25Nb-13Ta-5Zr alloy; e) Ti-30Nb-10Ta-5Zr alloy; f) Ti-30Nb-13Ta-5Zr alloy.

It was noted that the elements were fairly evenly distributed according to the volume of the ingots, based on the comparison of the compositions of alloys in randomly chosen areas of analysis, and also the good agreement (taking into account the measurement error) of the obtained values of the metal concentrations in the alloy with the calculated values expected on the basis of the selected samples of charge materials.

Photos of the alloys after melting are shown in Figure 4. A dendritic structure was shown, which is characteristic for alloys obtained by casting. The axes of 1 st, 2 nd and 3rd orders were marked. After annealing at $600^{\circ} \mathrm{C}$ for 12 hours in a vacuum, the structure of the ingots changed insignificantly (Figure 5). It can be noted that an increase in the concentration of tantalum promoted the enlargement of dendrites, while the concomitant increase in the concentration of niobium inhibited this growth. And with a content of $30 \% \mathrm{Nb}$, alloys with 10 and $13 \% \mathrm{Ta}$ had a completely identical structure.

After annealing at a temperature of $900^{\circ} \mathrm{C}$ for 12 hours in a vacuum, the structure of the ingots changed, recrystallization and growth of grains to millimeter sizes occurred (Figure 6). Thus, the optimal annealing temperature of $\mathrm{Ti}-(20-30) \mathrm{Nb}-(10-13) \mathrm{Ta}-5 \mathrm{Zr}$ alloys was assumed in the range from 600 to $900^{\circ} \mathrm{C}$ (most likely in the range of $600-700^{\circ} \mathrm{C}$, which requires a more detailed study).

The SEM images of the dendritic structures of the Ti-30Nb-13Ta$5 \mathrm{Zr}$ alloy were shown in Figure 7. The results of the elements distribution analysis in the dendritic structure of the Ti-30Nb-13Ta-5Zr alloy were presented in Figure 8. As can be seen from the photographs, niobium and zirconium were uniformly distributed the entire volume of samples, tantalum concentrated in the dendrites themselves, titanium was predominantly in the regions between the dendrite axes, but was also found in it. Also, inclusions in the basic structure, not containing at least titanium, were observed. They were also noticeable with a large increase in SEM images.

The mapping data obtained with Auger spectrometry were consistent with the results of X-ray diffractometry, which indicated that the elements of the alloy were not distributed in it by separate fragments, but were combined into a single structure (Figure 9). 
Citation: Nasakina EO, Konushkin SV, Baskakova MI, Fedyuk IM, Sergienko KV, et al. (2018) The Production of a Thin Wire of Ti-Nb-Ta-Zr Shape Memory Alloy for Medical Devices. J Material Sci Eng 7: 430. doi: 10.4172/2169-0022.1000430

Page 4 of 6

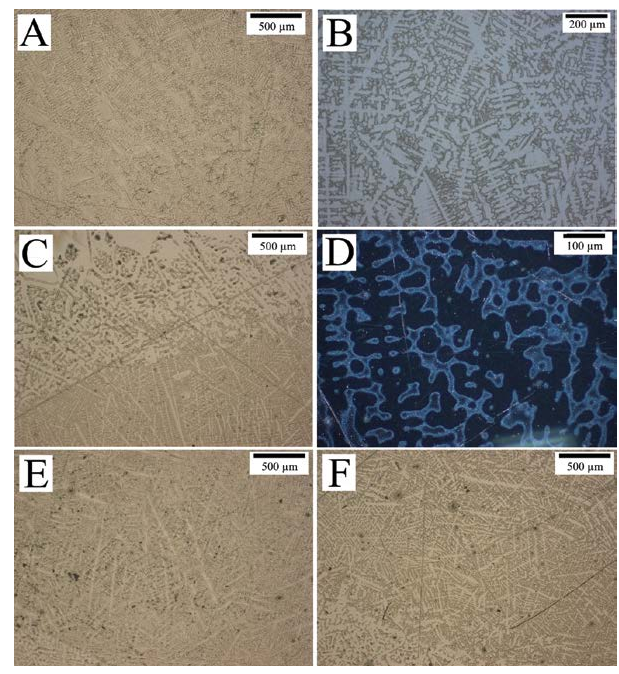

Figure 5: Microstructure of ingots after annealing at $600^{\circ} \mathrm{C}$ for 12 hours in vacuum: a) Ti-20Nb-10Ta-5Zr alloy; b) Ti-20Nb-13Ta-5Zr alloy; c) Ti-25Nb10Ta-5Zr alloy; d) Ti-25Nb-13Ta-5Zr alloy; e) Ti-30Nb-10Ta-5Zr alloy; f) Ti$30 \mathrm{Nb}-13 \mathrm{Ta}-5 \mathrm{Zr}$ alloy.

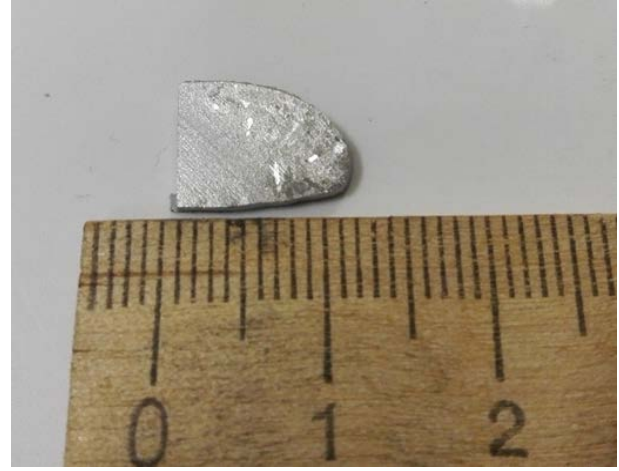

Figure 6: Microstructure of ingot of Ti-30Nb-10Ta-5Zr alloy after annealing at $900^{\circ} \mathrm{C}$ for 12 hours in vacuum.

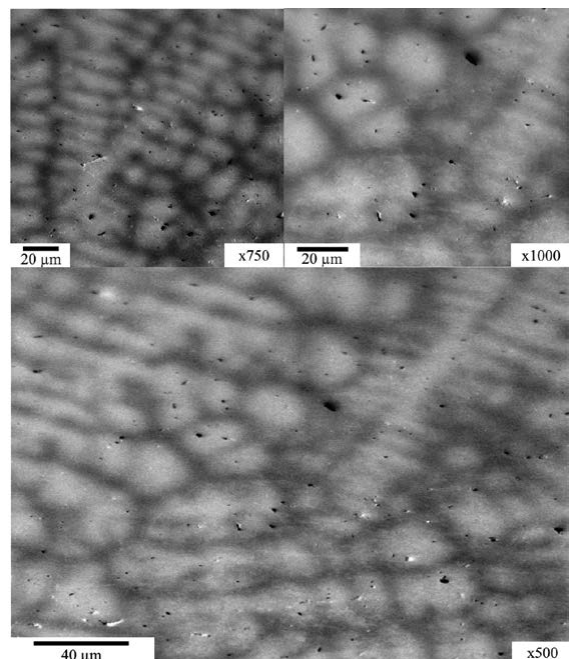

Figure 7: SEM images of dendritic structure of Ti-30Nb-13Ta-5Zr alloy after sevenfold remelting.

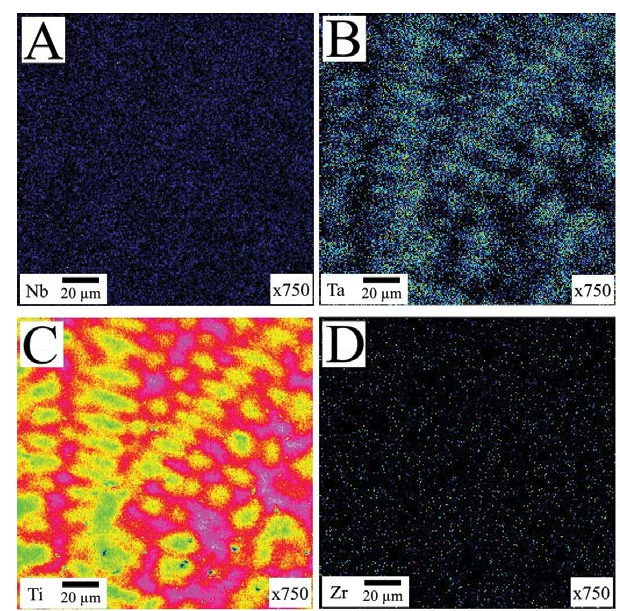

Figure 8: The elemental distribution of metals in the dendritic structure of the Ti-30Nb-13Ta-5Zr alloy according to the Auger spectroscopy: a) niobium; b) tantalum; c) titanium; d) zirconium.

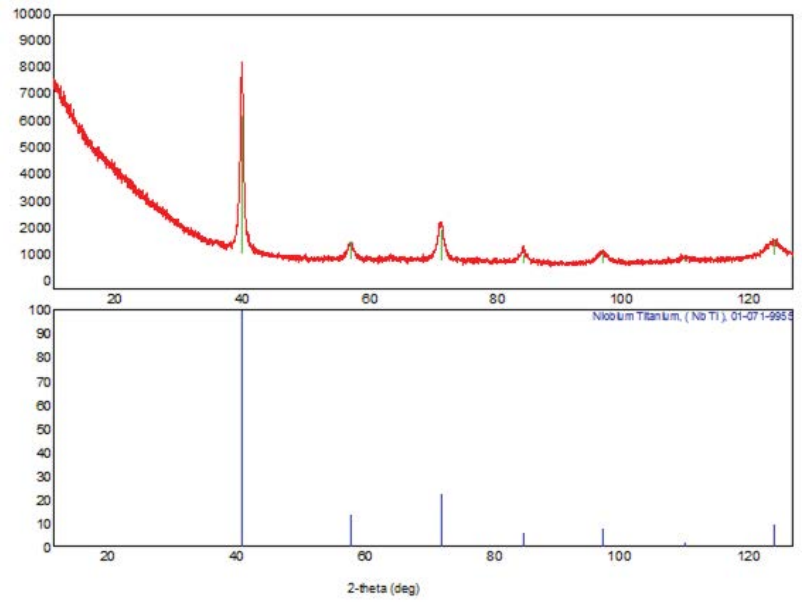

Figure 9: Results of X-ray analysis for Ti-25Nb-10Ta-5Zr alloy.

Photos of the microstructure of the $4 \mathrm{~mm}$ diameter bars of Ti-25Nb10Ta-5Zr and Ti-25Nb-13Ta-5Zr alloys after rotary forging were shown in Figure 10. The microstructure images of the wire after drawing were shown in Figure 11. Plastic deformation of ingots and rods passed with heating and annealing up to $600^{\circ} \mathrm{C}$ in air, but grain boundaries were not etched in microstructural analysis, which indicated that there was no recrystallization in alloys of all compositions [19]. Thus, as a result of plastic deformation, it is possible to obtain a wire with a nanostructure. This can be determined by transmission electron microscopy during subsequent studies.

The morphology of the Ti-20Nb-10Ta-5Zr alloy wire surface was shown in Figure 12. High roughness and heterogeneity were noted. It was of interest to study the structure of the surface in regions that differed from each other and at the same time regularly repeated. The composition of the wire surface in areas differing in the SEM image was shown in Figure 13. It is noticeable that in the analyzed areas it was different. Areas with a high carbon content presumably left after drawing (carbon-containing lubricant was used) and attached during numerous annealing were observed. In other areas, high oxygen content 
Citation: Nasakina EO, Konushkin SV, Baskakova MI, Fedyuk IM, Sergienko KV, et al. (2018) The Production of a Thin Wire of Ti-Nb-Ta-Zr Shape Memory Alloy for Medical Devices. J Material Sci Eng 7: 430. doi: 10.4172/2169-0022.1000430

Page 5 of 6
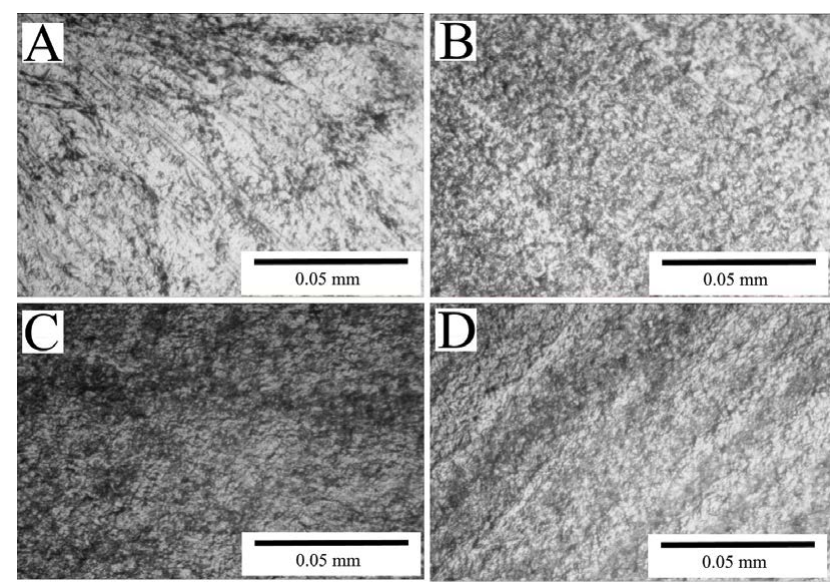

Figure 10: Microstructure of bars with a diameter of $4 \mathrm{~mm}$ : a) Ti-25Nb-10Ta$5 \mathrm{Zr}$ alloy, cross-section; b) alloy $\mathrm{Ti}-25 \mathrm{Nb}-13 \mathrm{Ta}-5 \mathrm{Zr}$, longitudinal section c) alloy $\mathrm{Ti}-25 \mathrm{Nb}-13 \mathrm{Ta}-5 \mathrm{Zr}$, cross-section; d) Ti-25Nb-13Ta-5Zr alloy, longitudinal section.
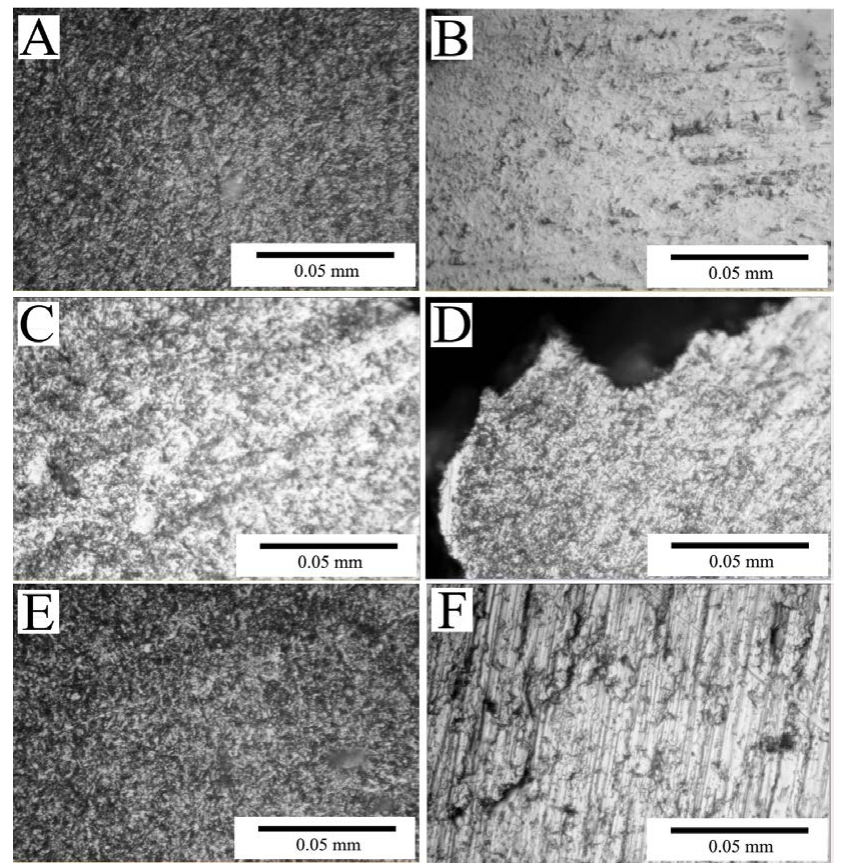

Figure 11: Microstructure of wire after drawing: a) alloy Ti-20Nb-10Ta-5Z b) Ti-20Nb-13Ta-5Zr alloy; c) Ti-25Nb-10Ta-5Zr alloy; d) Ti-25Nb-13Ta-5Zr alloy; e) Ti-30Nb-10Ta-5Zr alloy; f) Ti-30Nb-13Ta-5Zr alloy.

was observed, which is quite natural - all this metals actively adsorb this element, forming oxides, and almost any new surface is peculiar to their formation.

The morphology of the surface of the Ti-20Nb-10Ta-5Zr alloy wire after polishing was shown in Figure 14, and the wire surface composition was shown in Figure 15. It can be seen that after surface treatment, its uniformity increased. The content of tantalum and niobium was reduced to zero on the surface. While titanium and zirconium were contained in the amount of 5-10 percent and most likely formed oxides. The high content of carbon on the surface was associated with mechanical contamination of the surface.
Similar regularity was obtained for other compositions. It can be concluded that wires of any composition behave identically.

\section{Conclusion}

During the work, complex studies of the structure of the Ti-Nb-Ta$\mathrm{Zr}$ alloy in the form of samples of various configurations from ingots to wires with a diameter of $280 \mu \mathrm{m}$ were carried out.

It was shown that already three-fold re-melting of ingots makes it possible to obtain a fairly homogeneous chemical composition, but for further smelting of ingots it was decided to use a seven-fold re-melting of the ingots. The mass of ingots did not greatly affect the homogeneity

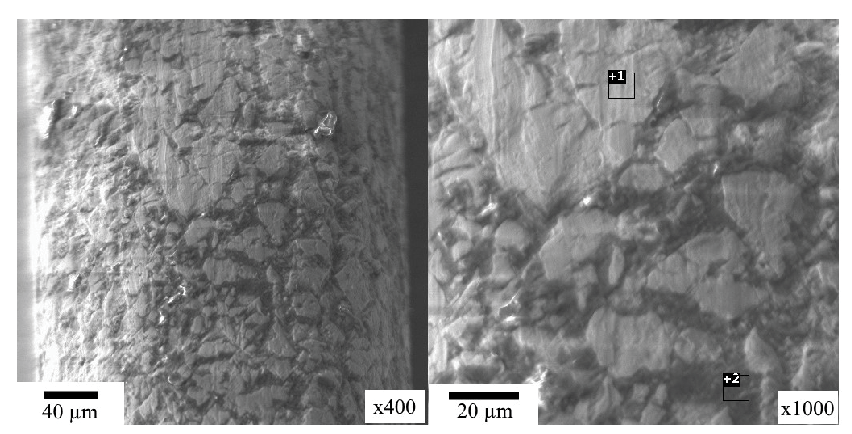

Figure 12: Morphology of the wire surface of the Ti-20Nb-10Ta-5Zr alloy and the analysis area with increasing.
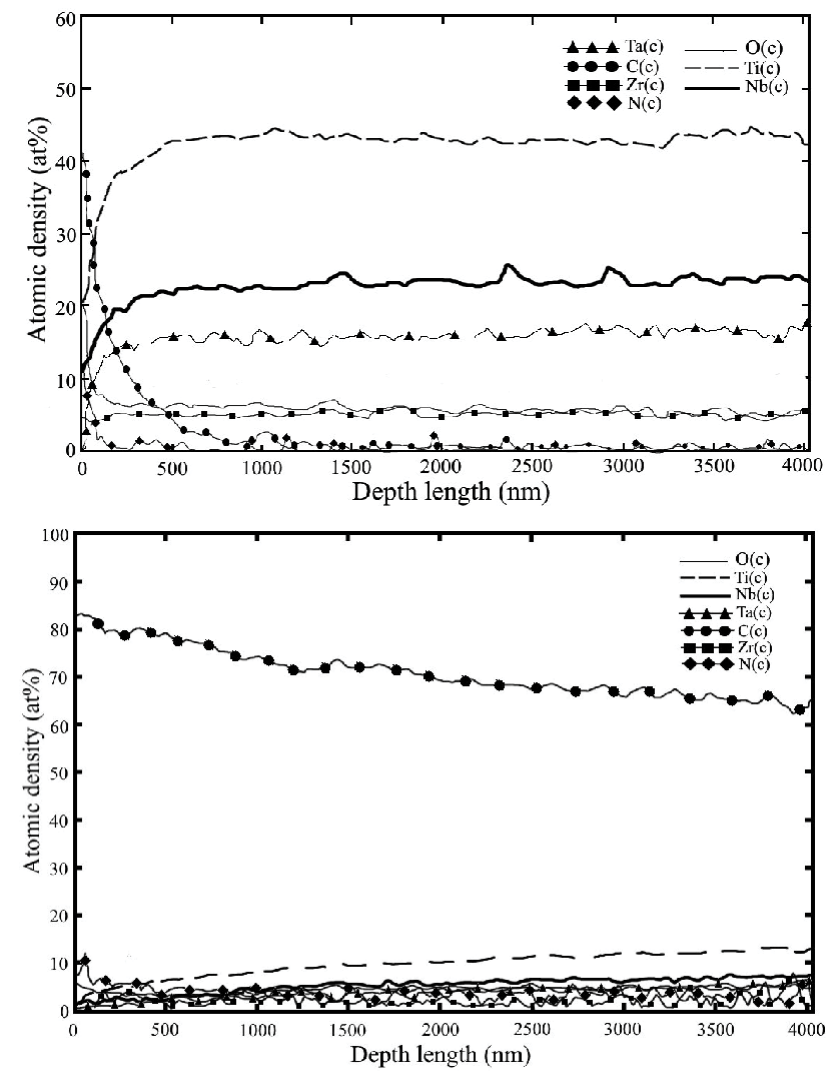

Figure 13: Composition of the wire surface of Ti-20Nb-10Ta-5Zr alloy according to the Auger spectroscopy: a) at point 1 (see Figure 12b); b) at point 2 (see Figure 12b). 


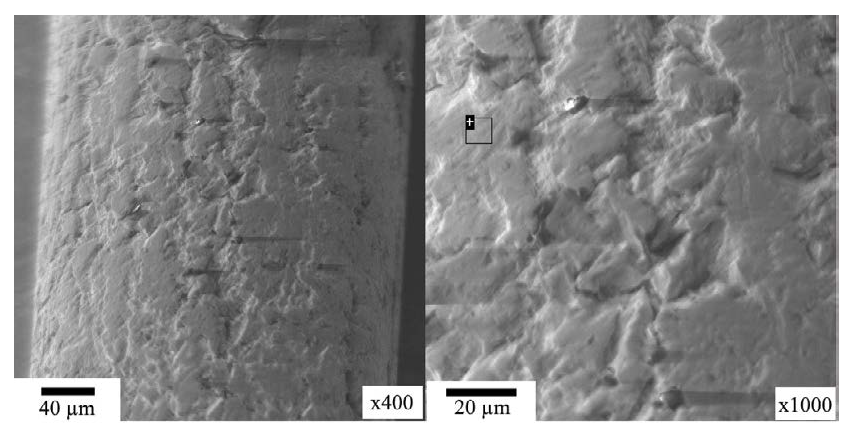

Figure 14: SEM image of the wire surface of Ti-20Nb-10Ta-5Zr alloy after polishing and analysis area with increasing.

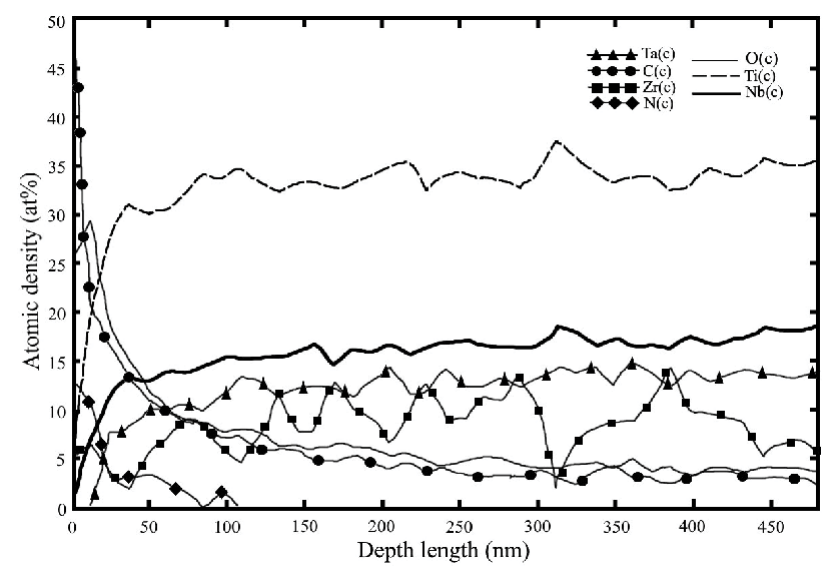

Figure 15: Ti-20Nb-10Ta-5Zr wire surface structure according to the Auger spectroscopy after polishing.

of the distribution of elements across the section. For the further smelting of ingots it was decided to make twenty-gram weights.

A fairly even distribution of the elements in the ingots volume, as well as a good coincidence of the obtained metal concentrations values with the calculated values expected on the basis of the selected samples of charge materials. It was noted that a uniform structure was obtained for all compositions, before and after homogenizing annealing.

The ingots have a dendritic structure characteristic of alloys obtained by casting. Niobium and zirconium were uniformly distributed throughout the sample, tantalum was concentrated in the dendrites themselves, titanium was predominantly in the regions between the dendritic axes, but is also found in it. X-ray diffractometry indicates that the elements of the alloy were not distributed in it by separate fragments, but were united in a single structure.

The optimal annealing temperature of $\mathrm{Ti}-(20-30) \mathrm{Nb}-(10-13) \mathrm{Ta}-$ $5 \mathrm{Zr}$ alloys was noted in the range from 600 to $900^{\circ} \mathrm{C}$.

The grain boundaries after plastic deformation and heat treatment were not identified in a microstructural analysis, which indicates that there was no recrystallization. It is possible that nanostructure was formed.

The morphology of wires of any composition after drawing shows a high heterogeneity, also two types of surfaces of different composition alternate - areas with a high content of carbon, presumably left after drawing, and with a high content of oxygen were observed. After mechanical treatment the surface, its uniformity increases.

\section{Acknowledgement}

The authors thank Golberg MA, Dyomin KY, and Mikhailova AB for their assistance with the sample analyses. This work was supported by the Ministry of Education and Science of Russia (grant identifier RFMEFI60417X0196).

\section{References}

1. Arena FJ (2013) Intravascular Ultrasound Evaluation of Interwoven Nitino Stents at Implant. Journal of Vascular Medicine \& Surgery.

2. Shabalovskaya SA, Tian H, Anderegg JW, Schryvers DU, Carroll WU, et al (2009) The influence of surface oxides on the distribution and release of nickel from Nitinol wires. Biomaterials 30: 468-477

3. Hu T, Chu C, Xin Y, Wu S, Yeung KW, et al. (2010) Corrosion products and mechanism on NiTi shape memory alloy in physiological environment. Journal of Materials Research 25: 350-358.

4. Trepanier C, Venugopalan R, Messer R, Zimmerman J, Pelton AR (2000) Effect of passivation treatments on nickel release from Nitinol. Proc Soc Biomater 1043.

5. Tomić S, Rudolf R, Brunčko M, Anžel I, Savić V, et al. (2012) Response of monocyte-derived dendritic cells to rapidly solidified nickel-titanium ribbons with shape memory properties. Eur Cell Mater 23: 58-80.

6. Trepanier C, Tabrizian M, Yahia LH, Bilodeau L, Piron DL (1998) Effect of modification of oxide layer on $\mathrm{NiTi}$ stent corrosion resistance. Journal of biomedical materials research 43: 433-440.

7. Trepanier C, Fino J, Zhu L, Pelton AR (2003) Corrosion resistance of oxidized nitinol. Proceedings of the International Conference on Shape Memory and Superelastic Technologies. SMST-2003

8. Zhu L, Trepanier C, Fino J, Pelton AR (2003) Oxidation of nitinol and its effect on corrosion resistance. In: Proceedings of the Conference on ASM Matererials. Medical Device.

9. Fattahzade M (2013) Improving corrosion resistance of porous nitinol samples by coating nano oxide layer through different methods. Proceedings of the 2 nd International Conference and Exhibition on Orthopedics \& Rheumatology.

10. Nasakina EO, Baikin AS, Sevost'yanov MA, Kolmakov AG, Zabolotnyi VT, et al. (2014) Properties of nanostructured titanium nickelide and composite based on it. Theoretical Foundations of Chemical Engineering 48: 477-486.

11. Nasakina EO, Sevost'yanov MA, Baikin AS, Seryogin AV, Konushkin SV, et al (2017) Applications of nano-structural shape memory alloy for medical devices. Proceedings of the 15th World Medical Nanotechnology Congress.

12. Nasakina EO, Sevost'yanov MA, Mikhailova AB, Gol'dberg MA, Demin KY et al. (2015) Preparation of a nanostructured shape memory composite material for biomedical applications. Inorg Mater 51: 400-404.

13. Nasakina EO, Baikin AS, Sergienko KV, Sevost'yanov MA, Kolmakov AG, et al. (2015) Biocompatibility of nanostructured nitinol with titanium or tantalum surface composite layers formed by magnetron sputtering. Doklady Chemistry 461: 86-88.

14. Sevost'yanov MA, Fedotov AY, Kolmakov AG, Zabolotnyi VT, Barinov SM et al. (2014) Mechanical properties of nanostructured nitinol/chitosan composite material. Inorganic Materials: Applied Research 5: 344-346.

15. Miyazaki S, Kim HY, Hosoda H (2006) Development and characterization of $\mathrm{Ni}$-free Ti-base shape memory and superelastic alloys. Mater Sci Eng A 438440: 18-24.

16. Le Gu'ehennec L, Soueidan A, Layrolle $P$, Amouriq $Y$ (2007) Surface treatments of titanium dental implants for rapid osseointegration. Dental Materials 23 844-854.

17. Tang X, Ahmed T, Rack HJ (2000) Phase transformations in Ti-Nb-Ta and TiNb-TaZr alloys. J Mater Sci 35: 1805-1811.

18. Yilmazer H, Niinomi M, Nakai M, Hieda J, Todaka Y, et al. (2012) Heterogeneous structure and mechanical hardness of biomedical $\beta$-type Ti-29Nb-13Ta-4.6Zr subjected to high-pressure torsion. Journal of the Mechanical Behavior of Biomedical Materials 10: 235-245.

19. Dubinskiy SM, Prokoshkin SD, Brailovski V, Inaekyan KE, Korotitskiy AV et al. (2011) Structure formation during thermomechanical processing of Ti-Nb$\mathrm{Zr}(\mathrm{Ta})$ alloys and manifestation of the shape-memory effect. The Physics of Metals and Metallography 112: 503-516. 